\title{
Malacological and parasitological surveys along the Xe Bangfai and its tributaries in Khammouane Province, Lao PDR
}

\author{
Suivis malacologiques et parasitologiques le long de la Rivière \\ Xe Bangfai et de ses affluents, Province de Khammouane, \\ Laos
}

\author{
Stephen W. Attwood ${ }^{(1)}$, Maud Cottet ${ }^{(2)}$ \\ (1) Department of Life Sciences, The Natural History Museum, London SW7 5BD, UK \\ (2) Water Quality and Biodiversity Dept. Nam Theun 2 Power Company Limited (NTPC) - Gnommalath Office \\ PO Box 5862, Vientiane, Lao PDR \\ mcottet.lao@gmail.com
}

\begin{abstract}
Malacological and parasitological observations were conducted along the Xe Bangfai River between 2010 and 2012 after a dermatitis outbreak. Mollusc populations were surveyed at 28 stations. Mollusc family and species lists were compiled. A sub-sample of 4033 snails from 10 gastropod families was screened for the presence of trematode cercariae. The findings demonstrated that mollusc populations declined after the initial operation of the Nam Theun 2 hydropower project. The species composition of the snail populations also underlined ecological changes. No definitive cause of cercarial dermatitis was found. However, cercariae resembling echinostome and xiphidiocercariae were respectively observed in one population of Bithyniidae and one population of Neotricula aperta. Further hydrobiological studies are thought to be necessary to study the succession of the molluscan community in the Xe Bangfai River until populations become stable.
\end{abstract}

Key words - cercariae, dermatitis, Neotricula aperta, Bithynia, hydro-power project

Résumé - Suite à des cas de dermatite observés le long de la Rivière Xe Bangfai, des observations malacologiques et parasitologiques ont été effectuées entre 2010 et 2012. Le suivi des populations de mollusques a été réalisé sur 28 stations. Les listes des familles et espèces de mollusques ont été inventoriées. Un sous-échantillon de 4033 mollusques, appartenant à 10 familles de gastéropodes, a été examiné pour rechercher la présence de cercaires de trématode. Les résultats décrivent un déclin des abondances des populations de mollusques consécutif aux relâchés de l'usine hydroélectrique Nam Theun 2. La composition taxonomique des populations de mollusques a également reflété les changements écologiques du milieu. Aucune cause de dermatite cercarienne n'a été établie. Cependant, des cercaires ressemblant aux echinostomes et xiphidiocercaires ont été respectivement 
observées dans une population de Bithyniidae et une population de Neotricula aperta. Des études hydrobiologiques supplémentaires sont jugées nécessaires afin de suivre l'évolution des populations de mollusques de la Rivière Xe Bangfai jusqu'à leur stabilisation.

Mots-clés - cercaires, dermatite, Neotricula aperta, Bithynia, projet hydroélectrique

\section{INTRODUCTION}

A malacological and parasitological survey was undertaken between May 2010 and May 2012 along the Xe Bangfai River, and some of its tributaries, in Khammouane Province (central part of Lao PDR). This survey was part of an investigation into the possible causes of cases of dermatitis that occurred in villages located along the Xe Bangfai River during the warm and dry season 2010 (April 2010). This river is situated in the Nam Theun 2 (NT2) hydro-power project area and receives water from the discharge channel of the NT2 Reservoir (Descloux et al., same issue), through the NT2 Downstream Channel. This form of dermatitis has been reported in association with various freshwater systems including natural and man-made lakes, rivers, and irrigation schemes. Dermatitis caused by contact with freshwater (e.g. washing, fishing activities, or rice plantation, etc.) can be explained by environmental factors such as contact with cyanobacteria and cyanobacterial toxins, but also by cercarial dermatitis and so a parasitological study was deemed necessary to consider this possibility.

Cercarial dermatitis results from the cutaneous allergic reaction in people exposed to larval schistosomes and other trematodes (cercariae) shed by infected snails into freshwater bodies such as lakes, ponds, and paddy fields.
The cercariae cause pruritis and papular eruptions, with often severe secondary infections, as they attempt to infect a non-permissive definitive host and die in the skin (Mulvihill \& Burnett, 1990). Schistosomes are parasitic fukes which infect mostly mammalian and avian definitive hosts (in which they lay eggs). In the life-cycle of most genera, the eggs, pass from the definitive host, hatch on contact with freshwater and release a free-swimming mobile larva which penetrates a compatible species of snail intermediate host and develops into a subsequent asexually reproducing intra-molluscan larval stage. After five or more weeks of development, a second mobile and penetrative larva, the cercaria, is released from infective snails. The cercariae penetrate a susceptible definitive host and the lifecycle is completed. In cases where the cercariae attempt to penetrate an incompatible host, they often die in the skin of the host and trigger an immune response; this is the mechanism of cercarial dermatitis. The most common cause of cercarial dermatitis in humans is the failed penetration of the skin by schistosomes of birds, which often produce vast numbers of large cercariae from individual snails.

In the Lao PDR the most likely cause of cercarial dermatitis is Schistosoma spindale cercariae shed by the pulmonate bulinine snail Indoplanorbis exustus, because this parasite is extremely 
prevalent in nearby Northeast Thailand (Liu et al., 2010). Indeed, I. exustus has been implicated in outbreaks of cercarial dermatitis in human populations in India (Narain et al., 1998; Narain \& Mahanta, 2000), the Lao PDR (Ditrich et al., 1992), Malaysia (Palmieri et al., 1977) and Thailand (Kullavanijaya \& Wongwaisaya, 1993; Nithiuthai et al., 2004). Other schistosomes likely to be implicated in an outbreak of cercarial dermatitis are Schistosoma spindale (Ditrich et al., 1992) and species of Trichobilharzia such as T. maegraithi (known from Thailand; Kruatrachue et al., 1968), T. brevis (Malay Peninsula), T. jianensis (Manchuria, China; Liu et al., 1977), and T. paoi (common across China; Tang \& Tang, 1962). The poorly documented genus Jilinobilharzia is also reported from Manchuria (Liu \& Bai, 1976) and might also occur in Laos; this genus has also been suggested as a cause of cercarial dermatitis (Kolárová, 2007). The aforementioned taxa are all parasites of anseriform birds, usually ducks (Anas spp. Aves: Anatidae) and most use pulmonate snails (Gastropoda: Pulmonata) as intermediate hosts. Other trematodes are reported as commonly occurring in Laos, such as Fasciolopsis buski, and Fasciola gigantica (Fasciolidae), Haplorchis taichui (Heterophyidae) and Opisthorchis viverrini (family Opisthorchiidae) (Ditrich et al., 1992); however, none of these is thought to be a significant causative agent of cercarial dermatitis. Unlike the schistosomatids above, these fasciolids, heterophyids and opisthorchids, shed cercariae which do not penetrate the definitive host directly, but encyst as metacercaria and await ingestion by a suitable host. The genera Dendritobilharzia and Macrobilharzia could potentially occur and cause dermatitis in Laos (Kolárová, 2007), but there are few reports of these genera from the region. Cercariae of Echinostomatidae might also be expected to be observed, but again these have not been cited as a likely cause of cercarial dermatitis. The species, genera and families of trematodes likely to be encountered in the investigation into the possibility of cercarial dermatitis along the Xe Bangfai, together with their known snail intermediate hosts, are listed in Table I.

Trematodes in the Lao PDR are commonly transmitted by both pulmonate and caenogastropod (prosobranch) snails (Tab. I); however, all species implicated as a significant cause of cercarial dermatitis are seen to be transmitted by pulmonate snails (mostly Lymnaeidae). Consequently, the initial phase of the investigation (i.e., prior to April 2011) focused on the pulmonates and the larger prosobranch snails collected as sympatrics. The latter phase of the investigation focused on the caenogatropods, especially the small triculine snails (Rissooidea: Pomatiopsidae: Triculinae) of the Xe Bangfai drainage, because the region was known to have a very high diversity of Triculinae (Davis, 1979; Attwood, 2009) and many of these taxa are known to act as hosts for species of trematodes (e.g., Echinostoma, Schistosoma and Paragonimus) (Attwood, 2010).

Consequently, the aims of the investigation were (i) to survey the areas around the villages from which dermatitis was reported, including the associated/connected drainage systems (ii) to identify mollusc species or 
Table I. Snail intermediate hosts of schistosomes potentially causing cercarial dermatitis (CD) in Laos, and of other trematodes likely to be found in the region, but not commonly associated with $\mathrm{CD}$. The definitive host (DH) group is also given. * denotes parasites which have been reported to infect humans. Source Attwood (2010).

Tableau I. Mollusques définis comme hôtes intermédiaires des schistosomes causant potentiellement des dermatites liées aux cercaires (CD) au Laos et autres trématodes susceptibles d'être présents dans la région mais pas obligatoirement associés aux $\mathrm{CD}$. Hôte définitif $(\mathrm{DH}) .{ }^{*}$ indique les parasites pouvant infecter les humains. Source Attwood (2010).

\begin{tabular}{|c|c|c|c|c|}
\hline Taxon & Family & $\begin{array}{l}\text { Snail intermediate hosts } \\
\text { (in Southeast Asia) }\end{array}$ & CD & DH \\
\hline $\begin{array}{l}\text { Echinostoma } \\
\text { spp. }\end{array}$ & Echinostomatidae & \begin{tabular}{|c|} 
Radix auricularia (Heterobranchia: \\
Lymnaeidae), Gyraulus, Hippeutis\& \\
Segmentina spp. (Heterobranchia: \\
Planorbidae: Planorbinae) \\
Bithyniidae (Caenogastropoda: \\
Rissooidea) \\
Tarebia \& Thiara spp. \\
(Caenogastropoda: Cerithioidea) \\
Filopaludina spp. \\
(Caenogastropoda: Viviparoidea)
\end{tabular} & No & $\begin{array}{l}\text { Aves, } \\
\text { Mammals, }\end{array}$ \\
\hline $\begin{array}{l}\text { Fasciola } \\
\text { gigantica }\end{array}$ & Fasciolidae & $\begin{array}{l}\text { Radix viridis \& Radix swinhoei } \\
\text { (Radix auricularia complex) } \\
\text { (Heterobranchia: Lymnaeidae) }\end{array}$ & No & $\begin{array}{l}\text { Artiodactyla, } \\
\text { Perissodactyla, }{ }^{*}\end{array}$ \\
\hline $\begin{array}{l}\text { Fasciolopsis } \\
\text { buski }\end{array}$ & Fasciolidae & $\begin{array}{l}\text { Hippeutis \& Segmentina spp. } \\
\text { (Heterobranchia: Planorbinae) }\end{array}$ & No & Mammals, ${ }^{\star}$ \\
\hline $\begin{array}{l}\text { Haplorchis } \\
\text { spp. }\end{array}$ & Heterophyidae & $\begin{array}{l}\text { Melanoides, Tarebia \& Thiara spp. } \\
\text { (Caenogastropoda: Cerithioidea) }\end{array}$ & No & $\begin{array}{c}\text { Aves, } \\
\text { Mammals, }\end{array}$ \\
\hline $\begin{array}{l}\text { Jilinobilharzia } \\
\text { spp. }\end{array}$ & Schistosomatidae & Heterobranchia (data deficient) & Yes & $\begin{array}{c}\text { Aves } \\
\text { (Anas spp.) }\end{array}$ \\
\hline $\begin{array}{l}\text { Opisthorchis } \\
\text { viverrini }\end{array}$ & Opisthorchiidae & \begin{tabular}{|} 
Bithynia (s) funiculate, Bithynia \\
(s) goniomphalos \& Bithynia (s) \\
siamensis Caenogastropoda: \\
Rissooidea: Bithyniidae); \\
Melanoides sp. (Caenogastropoda: \\
Cerithioidea)??
\end{tabular} & No & $\begin{array}{l}\text { Piscivorous } \\
\text { mammals, * }\end{array}$ \\
\hline $\begin{array}{l}\text { Schistosoma } \\
\text { mekongi }\end{array}$ & Schistosomatidae & $\begin{array}{c}\text { Neotricula aperta } \\
\text { (Caenogastropoda: Rissooidea: } \\
\text { Pomatiopsidae: Triculinae) }\end{array}$ & No & Mammals, ${ }^{*}$ \\
\hline $\begin{array}{l}\text { Schistosoma } \\
\text { ovuncatum }\end{array}$ & Schistosomatidae & $\begin{array}{c}\text { Tricula bollingi } \\
\text { (Caenogastropoda: Rissooidea: } \\
\text { Pomatiopsidae: Triculinae) }\end{array}$ & No & Rodentia \\
\hline
\end{tabular}


Table I. Continued.

Tableau I. Suite.

\begin{tabular}{|c|l|c|l|c|}
\hline Taxon & Family & $\begin{array}{c}\text { Snail intermediate hosts } \\
\text { (in Southeast Asia) }\end{array}$ & CD & DH \\
\hline $\begin{array}{c}\text { Schistosoma } \\
\text { sinensium }\end{array}$ & Schistosomatidae & $\begin{array}{c}\text { Tricula bollingi (Caenogastropoda: } \\
\text { Rissooidea: Pomatiopsidae: } \\
\text { Triculinae) }\end{array}$ & No & Rodentia \\
\hline $\begin{array}{c}\text { Schistosoma } \\
\text { spindale }\end{array}$ & Schistosomatidae & $\begin{array}{c}\text { Lymnaea acuminata } \\
\text { (Heterobranchia: Lymnaeidae), } \\
\text { Indoplanorbis exustus } \\
\text { (Heterobranchia: Planorbidae: } \\
\text { Bulininae) }\end{array}$ & Yes & $\begin{array}{c}\text { Artiodactyla, } \\
\text { Rodentia }\end{array}$ \\
\hline $\begin{array}{c}\text { Paragonimus spp. } \\
\text { Trichobilharzia } \\
\text { brevis }\end{array}$ & Troglotrematidae & $\begin{array}{c}\text { Tarebia spp. (Caenogastropoda: } \\
\text { Cerithioidea); some Triculinae }\end{array}$ & No & Mammals, ${ }^{*}$ \\
\hline $\begin{array}{c}\text { Trichobilharzia } \\
\text { jianensis }\end{array}$ & Schistosomatidae & $\begin{array}{c}\text { Radix (auricularia) rubiginosa } \\
\text { (Heterobranchia: Lymnaeidae) }\end{array}$ & Yes & $\begin{array}{c}\text { Aves } \\
\text { (Anas spp.) })\end{array}$ \\
\hline $\begin{array}{c}\text { Trichobilharzia (Heterobranchia: } \\
\text { maegraithi }\end{array}$ & Schistosomatidae & $\begin{array}{c}\text { Radix (auricularia) rubiginosa } \\
\text { (Heterobranchia: Lymnaeidae) }\end{array}$ & $\begin{array}{c}\text { Aves } \\
\text { (Anas spp.) }\end{array}$ & $\begin{array}{c}\text { Aves } \\
\text { (Anas spp.) }\end{array}$ \\
\hline $\begin{array}{c}\text { Trichobilharzia } \\
\text { paoi }\end{array}$ & Schistosomatidae & $\begin{array}{c}\text { Radix plicatula, Austropeplea ollula } \\
\text { (syn. Lymnaea ollula) } \\
\text { (Heterobranchia: Lymnaeidae) }\end{array}$ & $\begin{array}{c}\text { Aves } \\
\text { (Anas spp.) }\end{array}$ \\
\hline
\end{tabular}

* The cercariae reported by these authors (De et al., 2003) have not been corroborated by any other study.

families present at each study site, and to sample the most abundant species and (iii) to check for cercariae in molluscs. Any cercariae found were examined and the presence of known dermatitis-causing cercariae noted (with reference to Tab. I). Areas known to have been affected by the operation of the NT2 project were also studied, to assess changes in the abundance of mollusc species, in order to detect any changes which might facilitate an outbreak of cercarial dermatitis. Any other obvious environmental changes in the reporting villages, which might offer alternative explanations for the occurrence of dermatitis in 2010 were taken into account. The findings of the malacological and parasitological investigations are presented here, together with an assessment of the current likelihood of cercarial dermatitis along the Xe Bangfai River and the changes linked to the NT2 project.

\section{MATERIALS AND METHODS}

\subsection{Study area description}

The Nam Theun 2 (NT2) is a transbasin hydro-power project located in 
the central Lao PDR, Khammouane Province. Its design leads to a diversion of water from the Nam Theun 2 Reservoir to the Xe Bangfai River (XBF) southwards. The main structures of NT2 are the Nakai Dam, a Reservoir $\left(489 \mathrm{~km}^{2}\right.$ at its full supply level reducing to a potential minimum $86 \mathrm{~km}^{2}$ at the end of the dry season), a Power House, a Regulating Pond (capacity 8 million $\mathrm{m}^{3}$ ) and the $27 \mathrm{~km}$ long NT2 Downstream Channel releasing water into the $\mathrm{Xe}$ Bangfai River $10.5 \mathrm{~km}$ upstream of Mahaxai village (Fig. 2). Detailed features of this project are described in Descloux et al. (same issue). NT2 began generating 1,070 MW electricity for commercial purposes in April 2010; this was also the time at which the low water period (warm and dry season) of the Xe Bangfai was first affected by the release of the NT2 project. The flow rate of the discharge via the NT2 Downstream Channel ranges from 0 to $333 \mathrm{~m}^{3} \cdot \mathrm{s}^{-1}$ with an annual average of $220 \mathrm{~m}^{3} . \mathrm{s}^{-1}$ since March 2010 interrupted by three outages (three to five days) when flow to the NT2 Downstream Channel was cut for operational reasons.

\subsection{Sampling programme}

All stations monitored for the investigations are reported in Figure 2.

The monitoring of aquatic invertebrates has been undertaken along the Xe Bangfai River since 2010, with the year 2010 as a baseline survey. Malacological data from this monitoring program were incorporated into the investigation of the dermatitis outbreak. A total of 10684 snails were examined and identified to family level, at 2 sites on the river from 2010 to 2012 . The sites were respectively XBF0-2010 (Ban Elan) which was excluded from monitoring in 2011 because of the presence of backwater effects, and was replaced by XBFO (Ban Hai, located upstream of the confluence with the NT2 Downstream Channel) and the second site was the original XBF2 situated at Ban Mahaxai (9 km downstream of the confluence of the Xe Bangfai and the discharge channel - NT2 Downstream Channel). Samples were taken on eight dates, regularly distributed throughout the warm and dry season periods of 2010, 2011 and 2012 when the water level was low. These stations were also monitored during the outage of March 2011. In addition to this routine monitoring, further stations were added during the investigation of the dermatitis outbreak. Consequently, the investigation is composed of 2 phases as described below.

The first phase of the investigation linked to the dermatitis outbreak comprised a succession of surveys from May 2010 until March 2011. The first survey in this context was conducted by NTPC in May 2010 in Ban Phova (a village in front of Ban Mahaxai - XBF2, where the malacology baseline survey is available) where cases of dermatitis had been reported (Fig. 1, area 2). This sampling program included biological and chemical aspects of the Xe Bangfai waters including cercariometry. A malacological survey on the Xe Bangfai River banks (which included all molluscs found) and a first parasitological investigation were carried out during the outage of September 2010. This survey took place at three sites along 


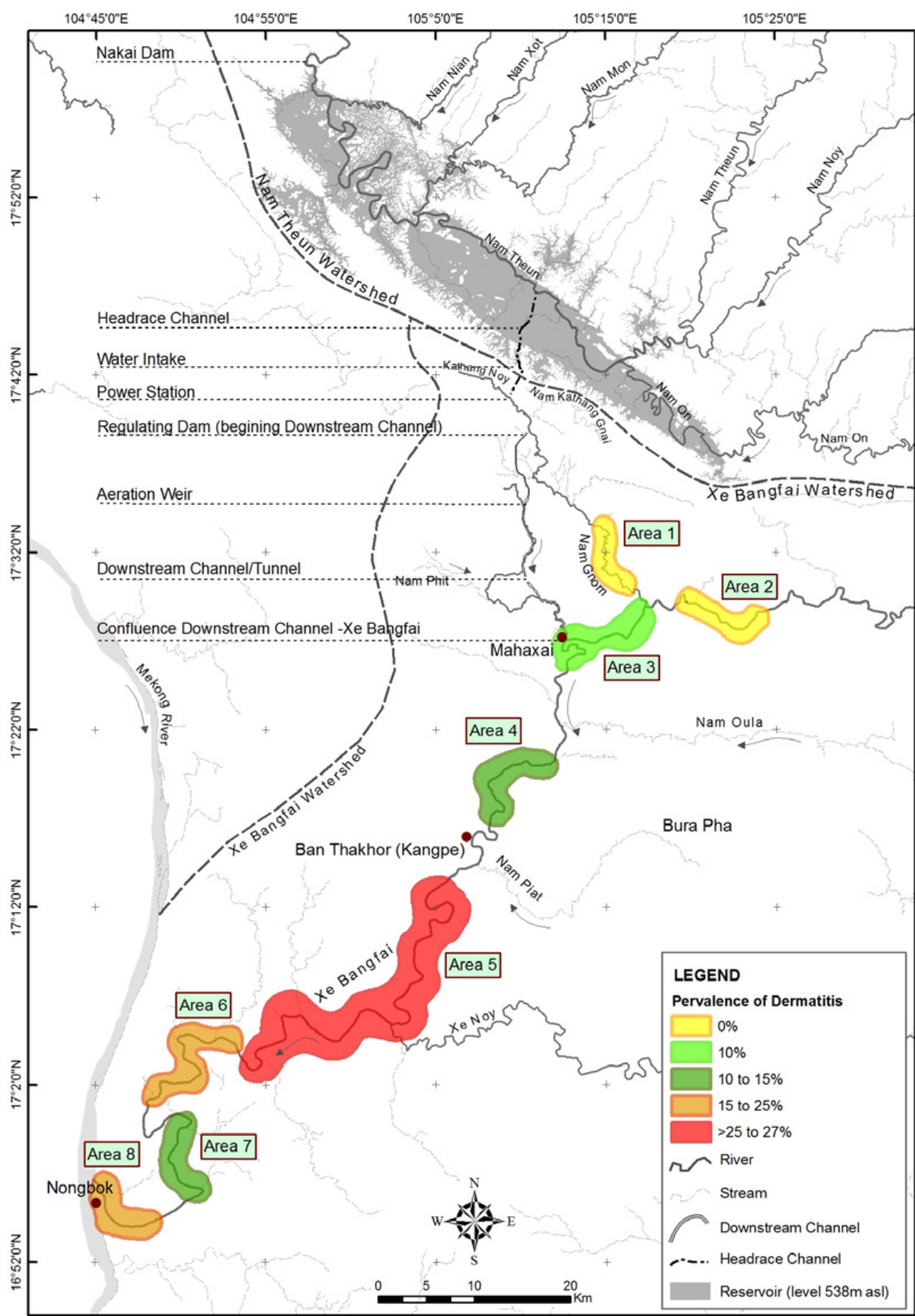

Fig. 1. Dermatitis prevalence along the Xe Bangfai River during the 2010 outbreak.

Fig. 1. Prévalence des cas de dermatites le long de la rivière Xe Bangfai en 2010. 
the NT2 Downstream Channel, one on the NT2 Downstream Channel around $20 \mathrm{~km}$ upstream of the confluence with the Xe Bangfai River, a second at the confluence of the Nam Phit and the NT2 Downstream Channel (Station 2: downstream of $\mathrm{DCH} 4$ ) and the third at the confluence of the NT2 Downstream Channel and the Xe Bangfai River (Station 3). This investigation aimed to detect intermediate hosts in areas upstream of the Xe Bangfai River which could have been an origin point for the dermatitis outbreak (release of cercariae). The survey focused on Lymnaeidae and Planorbidae, with snails screened for trematode infection by monitoring individual and pooled snails for cercarial emergence and by crushing snails to detect cercariae. Cercariometry was also used to detect any trematode larvae present in natural water bodies where snail intermediate hosts were expected to be found. This survey was repeated for these sites in January 2011 during the outage of the NT2 operations. An additional three sites were surveyed: one at Ban Mahaxai village (XBF2), one at Ban Elan (XBF0-2010) and one in Ban Thakhor (Kangpe) (Fig. 2), but no family of molluscs implicated in dermatitis (Lymnaeidae and Planorbidae) were found at these sites.

Another parasitological survey was undertaken in March 2011 at two sites on the lower Xe Bangfai River where new cases of dermatitis were reported. One site was on the lower Xe Bangfai River (near station 7, in Ban Nam Phou area), and the other on the lower Xe Bangfai river at Houyhe (Fig. 2). In addition to Lymnaeidae and Planorbidae, this survey also included Bithyniidae because they occurred in greater numbers at these sites than the pulmonates.

In the second phase of the investigation (from April 2011 onwards) the identification of molluscs was extended to the species level and the study area was expanded by 20 sites, to include additional drainages to those of the NT2 Downstream Channel and $\mathrm{Xe}$ Bangfai River. Parasitological surveillance excluded cercariometry, but a wider taxonomic range of molluscs was considered.

\subsection{Details of procedures}

\subsubsection{Methods used during the first phase of the investigation}

\section{Data from aquatic invertebrate monitoring}

Aquatic invertebrates were collected by a surber net ( $500 \mu \mathrm{m}$ mesh size) on the river banks at the station XBF0-2010, XBF0 (2011 onwards) and XBF2. Identification of aquatic invertebrates was performed to family level under a stereomicroscope in the laboratory. Malacological population data (densities $=$ ind $\mathrm{m}^{-2}$ ) were examined in order to reveal any molluscan population change, comparing before and after NT2 operation.

\section{Cercariometry}

In addition to direct observation of collected snails, cercariometry was also used to detect the presence of cercariae in the water column. Unlike direct observation, cercariometry can give an indication of whether potentially 


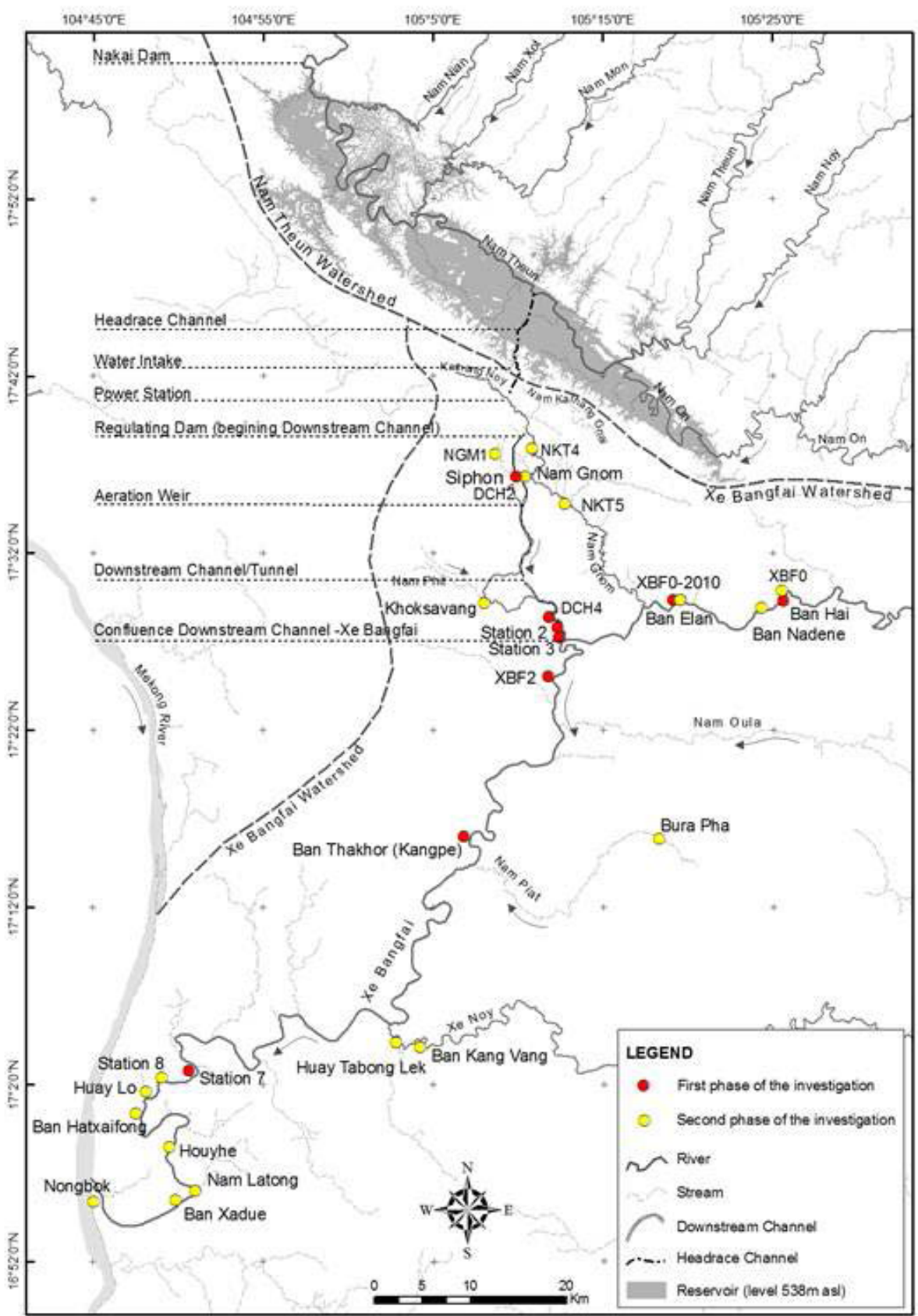

Fig. 2. Location of sampling sites.

Fig. 2. Localisation des sites de prélèvements. 
irritating cercariae are present in the waters contacted by local people, rather than simply shed in the laboratory by snails collected nearby. Indeed, cercariae causing dermatitis in a village might have originated from a snail population far upstream and not detected by our snail collections. A simple filtration technique has been developed for cercariometry (Kloos et al., 1982; Prentice, 1984; Théron, 1986) and widely adopted in transmission studies (Prentice \& Ouma, 1984; Kimura et al., 1994; Aoki et al., 2003). In the present study the technique adopted was that of Muhoho et al. (1997), briefly described as follows. A total of $50 \mathrm{~L}$ to $100 \mathrm{~L}$ of river or ditch water (depending on turbidity) were collected at each site and filtered through a $50 \mu \mathrm{m}$ sieve. Samples were examined under a stereomicroscope (Motic-K 20x/13) at magnification $\mathrm{x} 25$.

\section{Direct observation of snails for cercarial emergence}

Snails collected in the field were identified until the family level (minimum required). Individuals belonging to families known to be involved in parasite cycle were placed overnight individually in separated dishes with clean water under artificial light. The following morning the dishes were examined under a stereomicroscope at magnification $\times 25$ in order to check for the presence/absence of cercariae. Finally, some snails were crushed between 2 glass plates and examined under a stereomicroscope for the presence of parasite larvae in the snail tissues.

\subsubsection{Methods during the second phase of the investigation}

In April 2011, 21 sampling sites (Fig. 2) were selected on the basis of the following criteria. Sites were selected where the dermatitis was most prevalent in 2010 (following the advice of the NT2 Project public Health Department), and/or where the ecological conditions were likely to support persistent high population densities of snails, which could act as seeder populations for the lower Xe Bangfai.

At each site the snail species present were recorded and live samples taken of any species of medical importance or singular abundance. The population density was estimated for any species found to occur in sufficiently high numbers as to be a potential cause of the 2010 dermatitis. The live samples were then placed in pots of water over night and checked for cercariae from 8 am to $11 \mathrm{am}$ the following day. The individual snails from any sample that shed cercariae were then crushed to release any parasites and the prevalence of infection noted. The cercariae released were also stained (Lugol's lodine) and photographed.

Identification of molluscan taxa followed previous authors (Brandt, 1968, 1970, 1974; Brandt \& Temcharoen, 1971; Davis, 1979). Selection of potential snail intermediate host species was based on earlier reports (Brandt, 1974; Combes et al., 1980; Attwood, 2010). 


\section{RESULTS}

\subsection{Malacological surveys}

\subsubsection{Data from aquatic invertebrates monitoring}

This survey reported the number of snails found at two sites along the $\mathrm{Xe}$ Bangfai River during the different campaign (XBF0-2010 (Ban Elan), XBF0 (Ban Hai) 2011 onwards and XBF2). The results of these collections are summarized in Figure 3. At XBF0-2010 although two families of bivalves (Fig. $3 A$ ) and four families of gastropods (Fig. 3B) were present in February 2010, the molluscan fauna was dominated by members of the Pomatiopsidae (all Triculinae), Lymnaeidae and Dreissenidae. The Triculinae were present at population densities that exceeded 8000 ind. $\mathrm{m}^{-2}$ and showed a high diversity. In contrast, by April 2010 a most depauperate molluscan fauna was found at XBF0-2010. The site XBF0-2010 lies $5 \mathrm{~km}$ upstream of the juncture of the NT2 Downstream Channel and the Xe Bangfai River. By February 2011, the Triculinae again dominate the fauna, but the densities of all molluscs at XBFO (now at Ban Hai not Elan) were far lower than observed at XBFO-2010 in February 2010. In April 2011 the fauna is dominated by Corbiculidae followed by Triculinae. From April 2011 onwards Bithyniidae become more prominent in the samples. Indeed, by February 2012 the collections comprised of mainly Bithyniidae, Viviparidae and Corbiculidae in fairly equal proportions. The general trend from February 2010 to February 2012 is a decline in Triculinae and pulmonates, with an accompanying increase in Bithyniidae and Viviparidae. The April 2012 sample from XBFO resembled the February 2010 collection at XBF0-2010, except Corbiculidae dominated, and showed a significant presence of Triculinae. Comparison of the outage samples between 2010 and 2011 reveal no common pattern; however, the 2011 outage sample shows a relatively high diversity of large prosobranch snails (e.g., Ampullaridae and Viviparidae). Water quality of the Xe Bangfai upstream remained unchanged. The only environmental parameter which changed at XBF0-2010 was the water level, which leads to a change of habitat affecting the mollusc families found after the NT2 operations.

Turning to XBF2, which is located $9 \mathrm{~km}$ downstream of the NT2 Downstream Channel, at Ban Mahaxai, the pattern observed at XBF0-2010 is again seen with a depauperate fauna observed since April 2010 (Fig. 3). At XBF2 in February 2010 the collections were dominated by high densities of Lymnaeidae followed by Triculinae, Dreissenidae and then Buccinidae. In subsequent samples there were fewer than five molluscs found, except for the 2011 outage and April 2012, when 17 and 12 Corbiculidae were found, respectively. The outages appeared to have no impact in restoring the molluscan community to its February 2010 level.

3.1.2 Data from malacological surveys in the first phase of the investigation

During the first phase, a malacological survey was conducted concentrating on the areas affected by the dermatitis outbreak, a small number of samples 


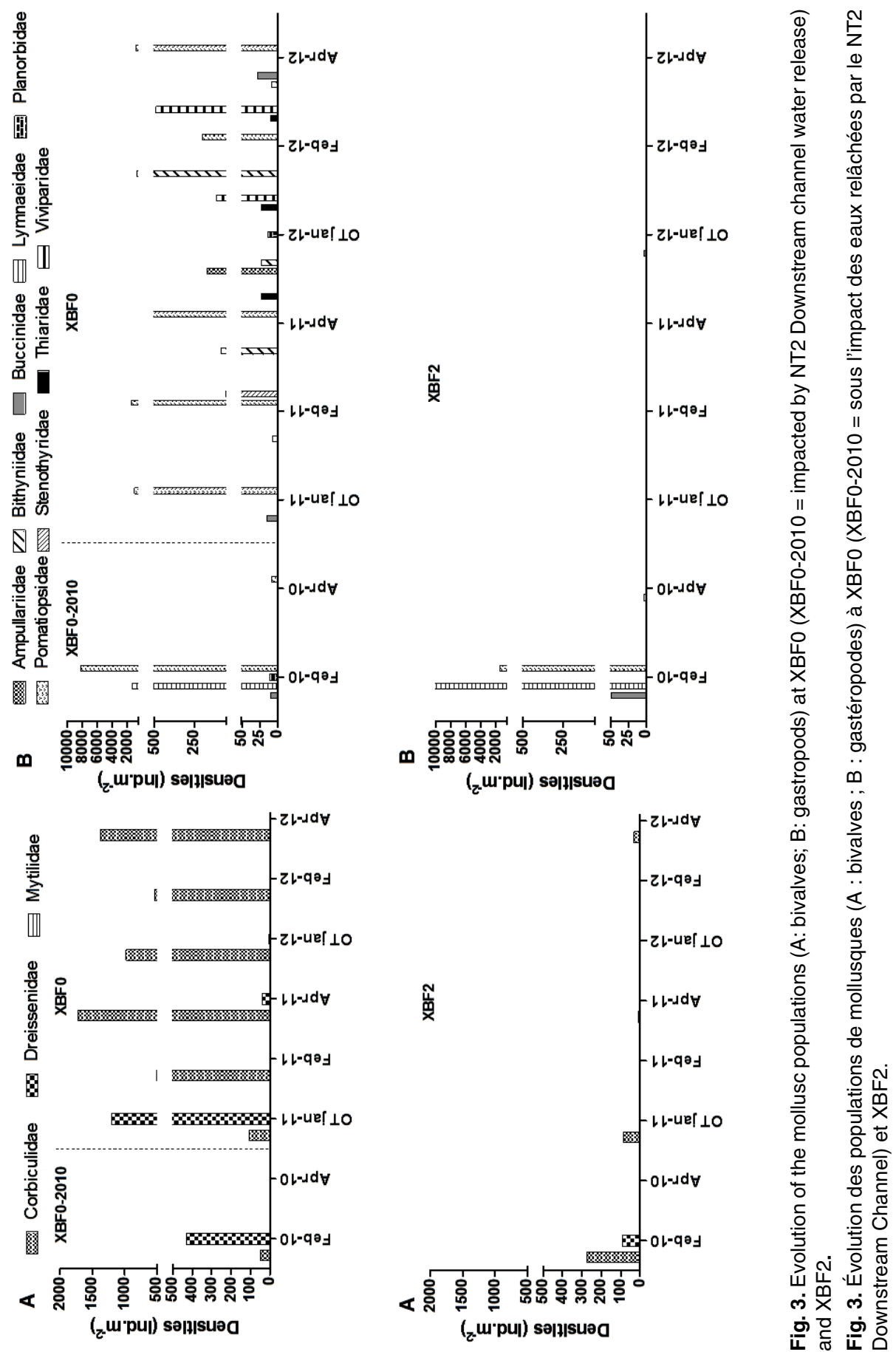


were taken in the NT2 Downstream Channel, the Xe Bangfai River (upstream of the confluence of the NT2 Downstream Channel, middle part and lower part) and also in associated water systems such as irrigation channels and rice fields (March 2011). The aim was to cover a large area and range of habitats so as to maximize the likelihood of detecting the origin of any cercarial dermatitis. The screening focused on pulmonate snails, which are often reported in the literature as associated with cercarial dermatitis. In September 2010, attempts were made to collect snails from 3 stations along the NT2 Downstream Channel; however, pulmonate snails were found only at the first station near the siphon (except for one lymnaeid found at Station 2, at the confluence with the Nam Phit).

During the field survey of January 2011 (NT2 Outage), no pulmonates (Planorbidae and Lymnaeidae) were found in the NT2 Downstream Channel (except at the station $20 \mathrm{~km}$ upstream of the confluence), and along the Xe Bangfai River. Villagers at Ban Thakhor (Kangpe) have shown shells of Indoplanorbis exustus and identified this snail as having been common in the low water period of 2010; they even called it "Itchy snail". However, no such snails were found at this site during January 2011 nor during the previous NT2 Downstream Channel survey of September 2010. In both these surveys, it appeared that pulmonate snails were found only in the upper regions of the NT2 Downstream Channel.
Results of the investigation conducted in March 2011 in the lower Xe Bangfai showed an abundant population of Bithyniidae in irrigation channels at both study sites (Houyhe and Namphou) and in rice fields at Houyhe. In this case, Bithyniidae were also collected for parasitological examination in the laboratory. The Molluscan fauna at this time also included other caenogastropods e.g. Buccinidae and Viviparidae.

3.1.3 Data from malacological surveys in the second phase of the investigation (April 2011)

The findings of the phase two malacological study are given in Table II. Some species are showed in Figure 4. The data show no correlation between the presence of species of snail commonly associated with cercarial dermatitis and the villages from which most reports of dermatitis originated. The results also show that the upper Xe Bangfai itself is dominated by small hydrobioid snails (Rissooidea), with no molluscs now found in the sites along the middle and lower Xe Bangfai. Those species commonly associated with cercarial dermatitis were not found along the Xe Bangfai River banks but in lentic systems near to the main river (e.g., marshes and pools) and in tributaries of this river (e.g. Nam Khatang River or Xe Noy River, Tab. II). Finally, the results suggest that the greater molluscan diversity occurs not in the $\mathrm{Xe}$ Bangfai but in small marshes, small tributaries and pools near to the main river. 
Table II. List of predominant gastropod species found in April 2011 at 21 sites around the NT2 project site in central Laos. Sample sites in bold are those from which most cases of dermatitis were reported in 2010; those with a * were sites where dermatitis was also reported in 2011. Taxa in bold are those commonly associated with cercarial dermatitis. Sample sites are listed from North to South, which is generally from upper to lower Xe Bangfai River (XBF).

Tableau II. Liste des espèces de gastéropodes dominantes trouvées en avril 2011 sur les 21 sites prospectés autour du projet NT2 situé au centre du Laos. Les sites d'échantillonnage en gras sont ceux pour lesquels la plupart des cas de dermatites ont été reportés en 2010 ; les sites annotés de * sont ceux où des cas de dermatites ont été reportés en 2011. Les taxa en gras sont généralement associés à des cas de dermatites liées aux cercaires. Les sites sont listés du Nord au Sud ce qui correspond pour l'essentiel des sites à une répartition de l'amont à l'aval de la Rivière Xe Bangfai (XBF).

\begin{tabular}{|c|c|c|}
\hline Sample site & Drainage & Taxa (listed in order of abundance) \\
\hline $\begin{array}{l}\text { NKT4 Ban Khout } \\
\text { Pha Dang }\end{array}$ & Nam Gnom & $\begin{array}{l}\text { Filopaludina (Siamopaludina) martensi (Caenogastropoda: } \\
\text { Viviparoidea); Pachydrobiella brevis (Caenogastropoda: } \\
\text { Rissooidea) }\end{array}$ \\
\hline $\begin{array}{l}\text { Ban Thathot } \\
\text { (NGM1upstream) }\end{array}$ & Nam Gnom & $\begin{array}{l}\text { Trochotaia sp. (Caenogastropoda: Viviparoidea); Neotricula aperta } \\
\text { (Caenogastropoda: Rissooidea) }\end{array}$ \\
\hline $\begin{array}{l}\text { Nam Gnom } \\
\text { Kathang }\end{array}$ & Nam Gnom & $\begin{array}{l}\text { Neotricula aperta (Caenogastropoda: Rissooidea); Semisulcospira } \\
\text { gredleri, Brotia (Brotia) bacata (Caenogastropoda: Cerithioidea); } \\
\text { Thiara scabra (Caenogastropoda: Cerithioidea); Stenothyra } \\
\text { hybocystoides (Caenogastropoda: Rissooidea); Clea Anentome } \\
\text { helena (Neogastropoda: Muricoidea) }\end{array}$ \\
\hline Siphon & Nam Gnom & $\begin{array}{l}\text { Tarebria granifera (Caenogastropoda: Cerithioidea); Melanoides } \\
\text { schmackeri (Caenogastropoda: Cerithioidea); Stenothyra crooki } \\
\text { (Caenogastropoda: Rissooidea); Uniandra subcircularis (Bivalvia: } \\
\text { Palaeoheterodonta); Indonaia humilis (Bivalvia: } \\
\text { Palaeoheterodonta) }\end{array}$ \\
\hline NKT5 Nam Gnom & & No molluscs found \\
\hline Ban Hai & $\begin{array}{l}\text { Upper Xe } \\
\text { Bangfai }\end{array}$ & $\begin{array}{l}\text { Pachydrobia prasongi (Caenogastropoda: Rissooidea); Stenothyra } \\
\text { hybocystoides (Caenogastropoda: Rissooidea); Semisulcospira } \\
\text { gredleri (Caenogastropoda: Cerithioidea); Hubendickia tuberculata } \\
\text { (Caenogastropoda: Rissooidea) }\end{array}$ \\
\hline Ban Elan & $\begin{array}{l}\text { Upper Xe } \\
\text { Bangfai }\end{array}$ & Stenothyra hybocystoides (Caenogastropoda: Rissooidea) \\
\hline Khoksavang & $\begin{array}{l}\text { Lake formed } \\
\text { by back } \\
\text { water from } \\
\text { Xe Bangfai } \\
\text { entering } \\
\text { Nong Oune } \\
\text { (Nam Phit) }\end{array}$ & $\begin{array}{l}\text { Lymnaea (Radix) auricularia rubiginosa (Pulmonata: } \\
\text { Lymnaeoidea) } \\
\text { Indoplanorbis exustus (Pulmonata: Planorboidea) } \\
\text { Hydrobioides nassa (Caenogastropoda: Rissooidea) } \\
\text { Wattebledia crosseana (Caenogastropoda: Rissooidea) } \\
\text { Filopaludina (Filopaludina) doliaris (Caenogastropoda: } \\
\text { Viviparoidea) }\end{array}$ \\
\hline Ban Nadene & $\begin{array}{l}\text { Upper Xe } \\
\text { Bangfai }\end{array}$ & $\begin{array}{l}\text { Stenothyra hybocystoides (Caenogastropoda: Rissooidea); } \\
\text { Pachydrobia prasongi (Caenogastropoda: Rissooidea); Paludomus } \\
\text { petrosus (Caenogastropoda: Cerithioidea) }\end{array}$ \\
\hline
\end{tabular}


Table II. Continued.

Tableau II. Suite.

\begin{tabular}{|c|c|c|}
\hline Sample site & Drainage & Taxa (listed in order of abundance) \\
\hline $\begin{array}{l}\text { (Kangpe) Ban } \\
\text { Thakhor }\end{array}$ & $\begin{array}{l}\text { Middle Xe } \\
\text { Bangfai } \\
\text { River }\end{array}$ & No molluscs found \\
\hline Bura Pha & Nam Piat & No molluscs found \\
\hline H. Tabong Lek & Xe Noy & No molluscs found \\
\hline Ban Kang Vang & Xe Noy & $\begin{array}{l}\text { Neotricula aperta (Caenogastropoda: Rissooidea); Clea Anentome } \\
\text { helena (Neogastropoda: Muricoidea) }\end{array}$ \\
\hline Station 7 & $\begin{array}{l}\text { Wetland(Low } \\
\text { er Xe } \\
\text { Bangfai) }\end{array}$ & No molluscs found \\
\hline Station 8 & $\begin{array}{l}\text { Rice field } \\
\text { (Lower Xe } \\
\text { Bangfai) }\end{array}$ & $\begin{array}{l}\text { Bithynia (Digoniostoma) siamensis siamensis (Caenogastropoda: } \\
\text { Rissooidea) }\end{array}$ \\
\hline Huay Lo & $\begin{array}{l}\text { Lower Xe } \\
\text { Bangfai }\end{array}$ & $\begin{array}{l}\text { Bithynia (Digoniostoma) siamensis goniomphalus } \\
\text { (Caenogastropoda: Rissooidea) }\end{array}$ \\
\hline Ban Ha Xai Fong & $\begin{array}{l}\text { Rice fields } \\
\text { near the } \\
\text { Lower Xe } \\
\text { Bangfai }\end{array}$ & $\begin{array}{l}\text { Bithynia (Digoniostoma) siamensis siamensis (Caenogastropoda: } \\
\text { Rissooidea); Clea Anentome helena (Neogastropoda: Muricoidea) }\end{array}$ \\
\hline Houyhe & $\begin{array}{l}\text { Houyhe near } \\
\text { the Lower Xe } \\
\text { Bangfai }\end{array}$ & $\begin{array}{l}\text { Bithynia (Gabbia) wykoffi (Caenogastropoda: Rissooidea); } \\
\text { Sinotaia mandahlbarthi (Caenogastropoda: Viviparoidea) }\end{array}$ \\
\hline Nam Latong* & Nam Latong & No molluscs found \\
\hline Nongbok* & $\begin{array}{l}\text { Ponds near } \\
\text { Lower Xe } \\
\text { Bangfai }\end{array}$ & $\begin{array}{l}\text { Bithynia (Digoniostoma) siamensis goniomphalus } \\
\text { (Caenogastropoda: Rissooidea); Pila polita (Caenogastropoda: } \\
\text { Viviparoidea); Pila ampullacea (Caenogastropoda: Viviparoidea); } \\
\text { Clea Anentome helena (Neogastropoda: Muricoidea) }\end{array}$ \\
\hline
\end{tabular}

\subsection{Parasitological results}

\subsubsection{Results from the first phase of the investigation}

In the first phase of the study, the initial cercariometry performed on the river bank at XBF2 in May 2010 did not reveal the presence of cercariae in the Xe Bangfai waters (filtered in the field). However, this result has been carefully taken into account because of the possibility of the decline of the dermatitis event at this time and the survey was undertaken at only one station.

During the survey of September 2010 , no cercariae were found in the water (cercariometry) for the different stations along the NT2 Downstream Channel. Of the snails from the station $20 \mathrm{~km}$ of the confluence with the $\mathrm{Xe}$ Bangfai River (the only station from 


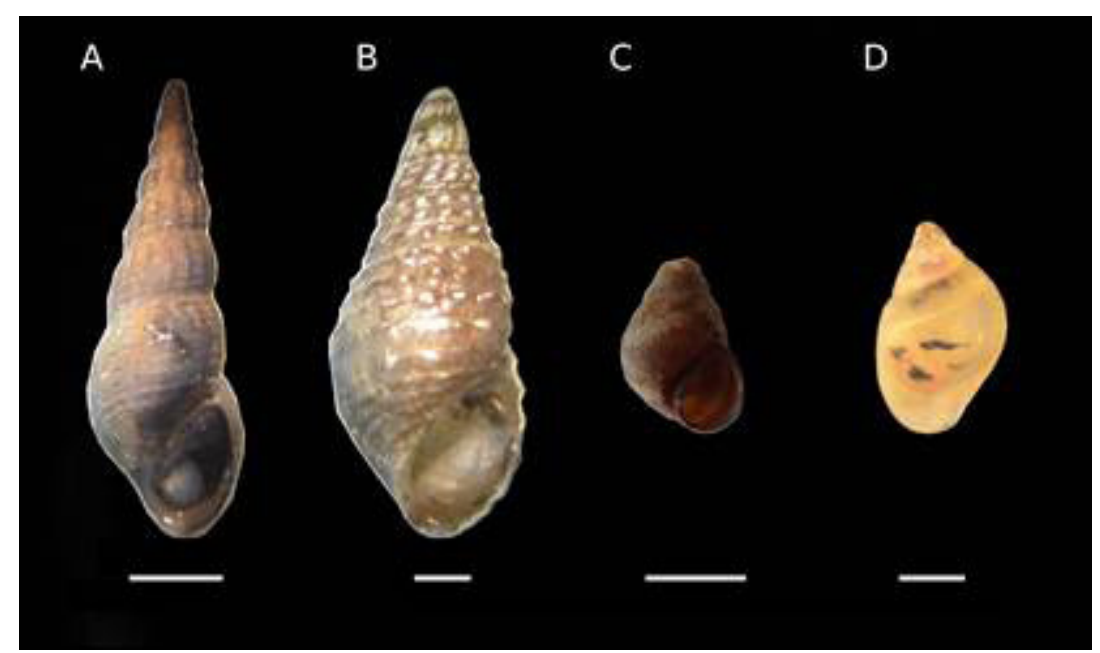

Fig. 4. Shells of some of the snail species encountered in the study area. A. Melanoides schmackeri (Caenogastropoda: Thiaridae). B. Semisulcospira gredleri (Caenogastropoda: Semisulcospiridae). C. Bithynia (Digoniostoma) siamensis goniomphalus (Caenogastropoda: Bithyniidae). D. Neotricula aperta (Caenogastropoda: Pomatiopsidae). Scale bars $5 \mathrm{~mm}$, except for $D$ which is $0.5 \mathrm{~mm}$.

Fig. 4. Coquilles de différentes espèces de mollusques trouvés dans la zone d'étude. A Melanoides schmackeri (Caenogastropoda: Thiaridae). B. Semisulcospira gredleri (Caenogastropoda : Semisulcospiridae). C. Bithynia (Digoniostoma) siamensis goniomphalus (Caenogastropoda : Bithyniidae). D. Neotricula aperta (Caenogastropoda : Pomatiopsidae). Les barres d'échelle $=5 \mathrm{~mm}$ sauf pour $\mathrm{D}$ qui est de $0,5 \mathrm{~mm}$.

which pulmonate snails were reported), 297 Lymnaeidae (97 checked individually, plus 4 sets of 50 pooled snails) and 23 Planorbidae were screened for cercarial emergence. None of the snails was found to harbor cercariae. In January 2011 (during the NT2 outage), a further 34 Lymnaeidae and 28 Planorbidae collected near the Siphon were checked and again none showed signs of shedding cercariae.

In the final parasitological study of phase one (March 2011), samples were taken from the upper part of the lower Xe Bangfai River (near station 7, Nam Phou area,) and the lower Xe Bangfai (at Houyhe). In this case, Bithyniidae were also examined because they were abundant in the irrigation channels at both sites and in the rice field at Houyhe. Other caenogastropods, present in the sampled areas, were also screened (Tab. III). All Buccinidae and Viviparidae screened were negative, but Bithyniidae from all three habitats and for both sites were found to harbor cercariae at infection rates of 1.37 to $8.21 \%$. Only one type of cercariae was observed and this resembled the cercaria of some members of the Echinostomatidae. During this survey, no cercariae were found in the Xe Bangfai waters and irrigation channel waters (by cercariometry). 
Table III. Results of screening for trematode infections among snails sampled from two sites on the lower Xe Bangfai River, during March 2011.

Tableau III. Résultats de la prospection d'une infection des mollusques par des trématodes. Mission au niveau de la Xe Bangfai aval réalisée en mars 2011.

\begin{tabular}{|c|c|c|c|c|}
\hline Site & Habitat & Taxon & $\begin{array}{c}\text { Number of } \\
\text { snails examined }\end{array}$ & $\begin{array}{c}\% \text { of snails found to } \\
\text { be infected }\end{array}$ \\
\hline \multirow{5}{*}{$\begin{array}{l}\text { Houy } \\
\text { he }\end{array}$} & \multirow{3}{*}{$\begin{array}{l}\text { Irrigation } \\
\text { channel }\end{array}$} & Bythiniidae (Bythinia sp) & 725 & 1.37 \\
\hline & & $\begin{array}{l}\text { Viviparidae } \\
\text { (Filopaludina } s p \text { ) }\end{array}$ & 2 & 0 \\
\hline & & Buccinidae (Clea sp) & 4 & 0 \\
\hline & \multirow[t]{2}{*}{ Rice field } & Bythiniidae (Bythinia sp) & 118 & 4.23 \\
\hline & & Viviparidae & 4 & 0 \\
\hline \multirow{3}{*}{$\begin{array}{l}\text { Nam } \\
\text { Phou }\end{array}$} & \multirow{3}{*}{$\begin{array}{l}\text { Irrigation } \\
\text { channel }\end{array}$} & Bythiniidae (Bythinia sp) & 329 & 8.21 \\
\hline & & $\begin{array}{c}\text { Viviparidae } \\
\text { (Filopaludina } s p \text { ) }\end{array}$ & 15 & 0 \\
\hline & & Buccinidae (Clea sp) & 2 & 0 \\
\hline
\end{tabular}

3.2.2 Results from the second phase of the investigation

In phase two of the investigation parasitological screening focused on any snail species which were observed to occur at high population densities in the areas where dermatitis had been reported. The findings of the screening activities are given in Table IV. Although species from five families, and across four different sampling sites covering the course of the Xe Bangfai from upper to lower, only in one case was a snail population found to release cercariae. Cercariae small; body: length approximately $130 \mu \mathrm{m}$ but protrusible, opaque, granular, pharyngeate, oral sucker terminal and bears small stylet, acetabulum well developed, situated mid-body; tail: aspinose, fin-folds present, brevi-cercous, shorter than body but protrusible; these were considered to be xiphidiocercariae
(Fig. 5) and were shed by Neotricula aperta from the Xe Noy (a small river) at Ban Kang Vang in the middle Xe Bangfai region, Savannakhet Province.

\section{DISCUSSION}

\subsection{Malacology}

In February 2010 the molluscan fauna at XBF0-2010 (NTPC survey near Ban Elan on the upper Xe Bangfai, Fig. 2), showed a high biodiversity and was dominated by triculine snails of the Pomatiopsidae; however, by April 2010 there were no molluscs found at the same site. In the Lao PDR, April has been cited as the time of year when population densities of adult Triculinae can be expected to reach their peak (Attwood, 1995), with population densities of Neotricula aperta alone reaching 
Table IV. Results of the phase two parasitological screening (29/04/11-02/05/2011).

Tableau IV. Résultats de la seconde étape de l'étude parasitaire (29/04/11 - 02/05/2011).

\begin{tabular}{|l|c|c|c|c|}
\hline \multicolumn{1}{|c|}{ Taxon } & Sample site & Drainage & $\begin{array}{c}\text { No. snails } \\
\text { examined }\end{array}$ & $\begin{array}{c}\% \\
\text { positive }\end{array}$ \\
\hline $\begin{array}{l}\text { Brotia B. bacata } \\
\text { (Cerithioidea: Pachychilidae) }\end{array}$ & $\begin{array}{c}\text { Nam Gnom/ } \\
\text { Kathang confluence }\end{array}$ & Nam Gnom & 144 & 0 \\
\hline $\begin{array}{l}\text { Indoplanorbis exustus } \\
\text { (Heterobranchia: Planorbidae) }\end{array}$ & Khoksavang & $\begin{array}{c}\text { Nam Phit } \\
\text { (Nong Oune) }\end{array}$ & 72 & 0 \\
\hline $\begin{array}{l}\text { Neotricula aperta } \\
\text { (Rissooidea: Pomatiopsidae) }\end{array}$ & Ban Kang Vang & Xe Noy & 2320 & 0.129 \\
\hline $\begin{array}{l}\text { Neotricula aperta } \\
\text { (Rissooidea: Pomatiopsidae) }\end{array}$ & $\begin{array}{c}\text { Nam Gnom/ } \\
\text { Kathang confluence }\end{array}$ & Nam Gnom & 154 & 0 \\
\hline $\begin{array}{l}\text { Radix rubiginosa } \\
\text { (Heterobranchia: Lymnaeidae) }\end{array}$ & Khoksavang & $\begin{array}{c}\text { Nong Oune } \\
\text { (Nam Phit) }\end{array}$ & 75 & 0 \\
\hline $\begin{array}{l}\text { Radix viridis } \\
\text { (Heterobranchia: Lymnaeidae) }\end{array}$ & Ban Xa Due & $\begin{array}{c}\text { Marsh (lower } \\
\text { Xe Bangfai) }\end{array}$ & 55 & 0 \\
\hline $\begin{array}{l}\text { Thiara scabra } \\
\text { (Cerithioidea: Thiaridae) }\end{array}$ & $\begin{array}{c}\text { Nam Gnom/ } \\
\text { Kathang confluence }\end{array}$ & Nam Gnom & 14 & 0 \\
\hline
\end{tabular}

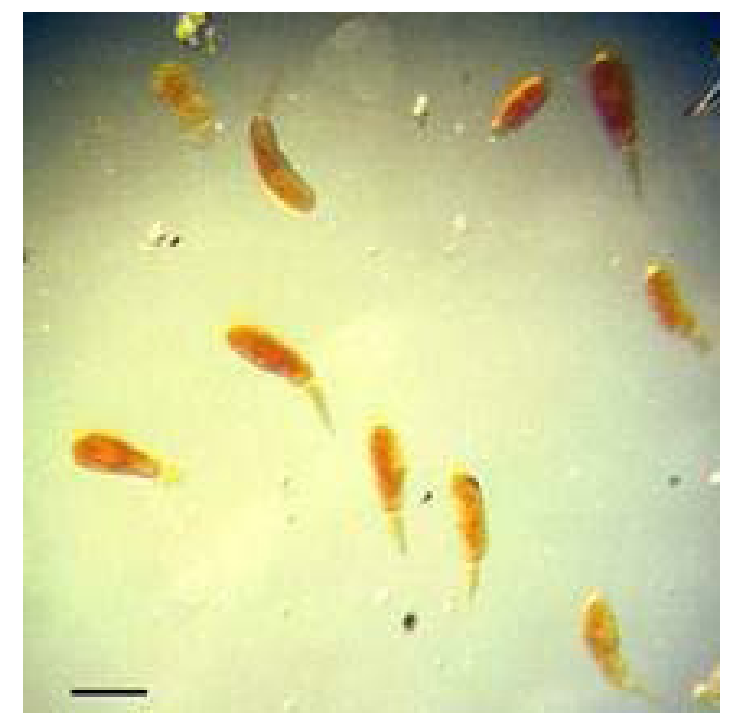

Fig. 5. Cercariae shed from Neotricula aperta collected from the Xe Noy River at Ban Kang Vang, Lao PDR. Scale bar $100 \mu \mathrm{m}$.

Fig. 5. Cercaires émises par Neotricula aperta, collectés au niveau de la rivière Xe Noy au village Ban Kang Vang, Laos. La barre d'échelle $=100 \mu \mathrm{m}$. 
levels of up to 4000 ind. $\mathrm{m}^{-2}$, on average across years, at XBF2 before the project (Attwood \& Upatham, 2012). Consequently, the normal expectation would be for population densities and biodiversity to have remained high or to increase as more snails grew in size and became detectable. The explanation for the absence of molluscs at XBF0-2010 in April 2010 is probably linked to the backwaters effect in the Xe Bangfai River due to the water release from the NT2 Downstream Channel. Indeed, even though the site lies $15.4 \mathrm{~km}$ upstream of the discharge channel, the water levels for the low water period (in April 2010) were observed to be higher than in previous years at XBF0-2010. The change of sampling from Ban Elan to Ban Hai (a shift $15.6 \mathrm{~km}$ upstream and out of the range of the backwater effect) in April 2011 resulted in the observation of higher population densities and diversities; this supports the conclusion that the main cause of the decline in molluscs was the change in habitat. The upstream XBFO (Ban Hai) showed a molluscan population dominated by Corbiculidae followed by Triculinae. The shift towards a predominance of Corbiculidae is not unexpected because these are a family of small clams which are able to attach themselves firmly to rocks in the river; these clams are also ovoviviparous and so do not need a stable and relatively unsilted substratum on which to lay eggs as the Triculinae do. Although, the density of Corbiculidae increased almost three-fold between 2010 and 2011, when the effects of deep water (backwaters) were removed by the change from a downstream (Ban Elan) to upstream site (Ban Hai), the population of Triculinae fell to $<10 \%$ of its original level, and mollusc population densities overall were much lower than in 2010. These observations suggest that the operation of NT2 effected a reduction in mollusc populations (especially of Triculinae) at XBF0-2010 through increase in water depth during the low water period.

The impact of increased NT2 flow on the total mollusc population is also seen in Figure 3, with population density at XBF2 declining gradually, but still to levels less than one fifth of their initial values. By February 2012 the collections at XBFO comprised of mainly Bithyniidae, Viviparidae and Corbiculidae in fairly equal proportions, with a decline in pulmonates and triculine snails. Unlike the Triculinae, which are small epilithic snails whose populations persist in an area, rapidly building up in the low water period (by recruitment from eggs laid on stones in the river the year before or by colonization from seeder populations upstream or in tributaries; Attwood et al., 2008), and which require shallow, clear, well-oxygenated waters to survive and reproduce; the Bithyniidae are larger snails, able to climb out of the water and survive for short periods, or to attach to aquatic plants and shelter from high current (Wächtler, 2001). Consequently, the Bithyniidae are better colonists and more flood resistant than the Triculinae and so expected to tolerate the effect of higher flow and water levels than the pomatiopsid snails. Similarly, the Viviparidae could be expected to gradually replace the normal low water molluscan fauna of the Xe Bangfai as time since first operation of NT2 increases. The Viviparidae are large 
snails, better able to deal with increased turbidity and a muddy substratum, able to survive longer out of water, and are good colonists. The Viviparidae are also ovoviviparous and, like the Corbiculidae, do not need a stable environment in which to deposit eggs. This family is moreover almost the only one still found in XBF2 site.

$\mathrm{XBF2}$, which is at Ban Mahaxai (9 km downstream of the NT2 Downstream Channel), showed a negligible molluscan fauna after February 2010. This observation is in agreement with earlier studies, which prior to 2006 reported very high population densities (> 5000 ind. $\mathrm{m}^{-2}$ ) of the snail Neotricula aperta (Triculinae) at Mahaxai (Attwood \& Upatham, 1999), but large decline of this population by 2011 , which was attributed to elimination of low water conditions by the release of the NT2 Power House (Attwood \& Upatham, 2012). For instance, calcium concentration changes could be an explanation of the decline of the population. Calcium concentration levels in the Xe Bangfai River remained unchanged during the wet season (June to November) but were seen to drop during the dry season (December to May) after the NT2 project began operation (Chanudet et al., same issue). However, the changes observed downstream and within the backwater reach of the Downstream Channel confluence are therefore most likely related to habitat change (water level and velocity) than to physic-chemical water composition (Chanudet et al., same issue).

The findings of the second phase malacological study failed to demonstrate any correlation between the presence of species of snail commonly associated with cercarial dermatitis and the villages from which most reports of dermatitis originated. This could be explained by the fact that ecological conditions have changed markedly in the river (especially during the March to May period when most Triculinae and Lymaeidae grow and reproduce in the Xe Bangfai) since the initial reports of dermatitis were received. The observations also indicated that the molluscan fauna of the upper Xe Bangfai itself was dominated by small hydrobioid snails (Rissooidea), with no molluscs now found in the sites along the middle and lower Xe Bangfai. Again this appears to be an effect of NT2 because previous studies report a high diversity of triculine snails in the middle Xe Bangfai (Attwood \& Upatham, 1999). In fact the present study found that those species commonly associated with cercarial dermatitis were not found in the $\mathrm{Xe}$ Bangfai River but in lentic systems near to the main river (e.g., marshes and pools) or in its tributaries (e.g. Nam Gnom, Xe Noy). Nevertheless, it is most likely that prior to March 2010, these snails were common in the $\mathrm{Xe}$ Bangfai. In support of this possibility, it is noteworthy that villagers at Ban Thakhor when shown shells of Indoplanorbis exustus identified this snail (and locally called "Itchy snail") as having been common in the low water period of 2010; however, no such snails were found at that site in the September 2010 survey.

\subsection{Parasitology}

In the first phase of the study, snails were screened for the presence/ emergence of cercariae in September 
2010, January (outage) and March of 2010/2011 and infected snails were detected only in March. In the September survey at station 1, 297 Lymnaeidae and 23 Planorbidae (Indoplanorbis) were screened for cercarial emergence, but all appeared negative. This maybe explained by the fact that, following marked ecological change effected by the onset of operations at NT2, most snail populations in the area would have been recently established. The pulmonate snails tend to be good colonists and so many populations are recently founded and/or temporary. Trematode infections tend to be more common in snail populations which have persisted long enough for parasite establishment to occur. Consequently, it would have been unlikely that the September 2010 populations had been found to shed cercariae. The January sample was rather small (34 Lymnaeidae and 28 Indoplanorbis), although where they occur, Schistosoma spindale and clinostomes (Trematoda: Clinostomatidae) occur at high prevalence in Indoplanorbis populations (Liu et al., 2010). Consequently, the snail populations may have been truly negative. However, again, so early in the low water period, the snail populations are likely to have been newly established (or re-established after the flood) and the trematode transmission season only just begun (i.e., infections might be absent or still pre-patent and undetectable).

Bithyniidae infection rate was not proportional to the number of snails examined. In contrast, the March 2011 survey did detect cercariae (Tab. III). Bithyniidae from all habitat types investigated and both sites were found to harbor cercariae at infection rates of 1.37 to $8.21 \%$. The fact that cercariae were found may be due to the survey being later in the transmission season, the fact that the samples were larger (1202 snails checked) or because Bithyniidae were included for the first time. A further factor possibly explaining the detection of infected snails is that more lentic habitats such as rice fields and stagnant channels and ditches were included. Miracidial success is greater in a slow moving or stagnant water body, thereby increasing the likelihood of snail infection. Thus it may be that if the dermatitis were linked to cercariae, the causative agents would be more likely to be found in water systems related to the Xe Bangfai River, rather than in the river itself.

In phase two of the investigation, screening included the Xe Bangfai mainstream and tributaries. These water systems, and especially the Nam Gnom area, were known to present dermatitis events few years previous to the project, as reported the local population. In this phase two, species from five families, and across four different sampling sites covering the course of the Xe Bangfai River from upper to lower (Tab. IV), were examined, but cercariae were only found to be shed by one population of Neotricula aperta from the Xe Noy (a small river) at Ban Kang Vang in the middle Xe Bangfai region (Savannakhet Province). Again this observation was made later in the low water period (April/May) when trematode infections are more likely to be detected. Although $N$. aperta is the intermediate host for Schistosoma mekongi, which is a parasite infecting humans, the cercariae observed in this 
study were not those of Schistosoma, but most closely resembled xiphidiocercaria. Incidentally, the cercariae of S. mekongi are not known to be greatly associated with cercarial dermatitis because they generally penetrate human skin eliciting little immune response. The prevalence in the snails was low $(0.129 \%)$, but $N$. aperta can occur at very high population densities and so could release enough cercariae into the river to cause dermatitis in humans, although cercariae of the kind observed are not yet reported as associated with human dermatitis. Further, the detection of cercariae in this population may have been due to the large sample size, and had other snails been sampled in the same numbers, dermatitis associated cercariae may have been found. On the other hand, the larger sample size reflects a larger population density in the field, and a dense snail population is more likely to be involved in the transmission of a trematode. It is also worth noting that all cases of dermatitis in 2011 were reported from downstream of the $\mathrm{Xe}$ Noy; this might be expected if these $N$. aperta populations were the source of cercariae causing dermatitis.

No (or very few) molluscs were found at survey sites on the lower $\mathrm{Xe}$ Bangfai; this suggests that, if the dermatitis in 2010 was cercarial dermatitis, the snails responsible are no longer present. Indeed, the people living along the lower Xe Bangfai reported that, from late March to the end of the dry season 2010 , they observed many snails around the bushes in the river. From their description these might have been species of Thiaridae and
Viviparidae - in this case it is unlikely that trematodes from these snails caused the dermatitis; however, there may have been smaller snails present that could cause itching but that were not noticed by the local people. It is hypothetical that large numbers of snails were washed downstream from the Xe Bangfai, around Mahaxai (Fig. 2, XBF2), in early March, as the NT2 Downstream Channel of the NT2 project began to discharge large volumes of water into the river just upstream of Mahaxai, and came to settle along the lower Xe Bangfai around Ban Kengpe. In support of this, it can be noted that the first major meander in the river (after Mahaxai) occurs near Ban Thakhor and therefore this is a likely place for the deposition of floating material. Prior to 2010, the Xe Bangfai at Ban Mahaxai supported a very high molluscan biodiversity and dense populations of snails such as Neotricula aperta (Attwood \& Upatham, 1999). The dry season of 2010 was, according to villagers, unusually long and would have allowed the displaced snails to become infected by local trematodes and shed cercariae for a prolonged period. Although populations of snails common at Mahaxai before the operation of NT2 could survive for a season washed up on river banks; they would die in the next wet season and be unable to repopulate the same areas in 2011, because their breeding habitats at Mahaxai had been changed to a persistent higher water level. Consequently, these snail populations would not recur in 2011 and this could explain the failure of dermatitis to reappear in most of the previously affected region. 


\section{CONCLUSION}

The investigations revealed that the onset of operation of the NT2 project coincided with a marked decline in selected Xe Bangfai River mollusc populations downstream of, or near to, the NT2 Downstream Channel. Whilst some recovery of populations was observed in the subsequent two years, there was no recovery among the Triculinae and little recovery of pulmonates, with a gradual increase in larger snails and snails better adapted to more muddy, deeper waters, and to dispersal and colonization (e.g., Bithyniidae, Corbiculidae and Viviparidae). The parasitological surveys found no obvious cause of cercarial dermatitis; however, the marked ecological changes following operation of NT2 meant that snail populations present in early 2010 , when most reports of dermatitis were made, were no longer present when the consequent investigations were performed. Also, for the same reason, many of the surveyed populations were probably recently established and there had been insufficient time for transmission to begin and patent infections arise. Cercariae were observed in one population of Bithynia and one population of Neotricula aperta (resembling echinostome and xiphidiocercariae, respectively), although none of these is reported to be associated with cercarial dermatitis.

In summary, the investigations have not confirmed cercarial dermatitis as a probably explanation for the dermatitis reported among villagers associated with the Xe Bangfai in 2010. The findings suggested that, if cercarial dermatitis were the cause it would be unlikely to recur because it would most likely have been caused by a combination of snails being washed downstream into the lower Xe Bangfai, when the NT2 project first began to operate, and the unusually long dry season in 2010. The molluscan fauna of the Xe Bangfai is clearly in a state of transition following the ecological changes associated with the onset of operation of the NT2 project. The dermatitis reported may have been caused by some temporary factor occurring at the time of initial operation of NT2, which may or may not have been directly associated with the NT2 project. Further studies are required to follow the succession of the molluscan community in the Xe Bangfai when the hydro-ecological system has found its new equilibrium.

\section{ACKNOWLEDGEMENTS}

The authors would like to thank everyone who contributed to the dermatitis investigation: the Nam Theun 2 Power Company in Lao PDR (whose Shareholders are Électricité de France, Lao Holding State Enterprise and Electricity Generating Public Company Limited of Thailand) and especially to $\operatorname{Dr} \mathrm{P}$. Sananikhom and Dr A. Silavong from the Health Program Management Unit of the Nam Theun 2 Power Company, the whole team of the Aquatic Environment Laboratory (AEL) of the Nam Theun 2 Power Company for the sampling and laboratory analysis, the logistic Division for their support, and GIS specialist (Mr Liankham Payasane). We are also grateful to the Dr Strobel and Pasteur Institute for their useful advices. Finally, we would like to 
thank referee useful and learned comments that helped for the manuscript improvement.

\section{REFERENCES}

Aoki Y., Sato K., Muhoho N.D., Noda S. \& Kimura E., 2003. Cercariometry for detection of transmission sites for schistosomiasis. Parasitol. Int. 52 : 403-408.

Attwood S.W., 1995. A demographic analysis of y-Neotricula aperta (Gastropoda: Pomatiopsidae) populations in Thailand and southern Laos, in relation to the transmission of schistosomiasis. J. MolIuscan Stud. 61 : 29-42.

Attwood S.W., 2009. Mekong Schistosomiasis: Where Did It Come from and Where Is It Going? In: Campbell IC (Ed.), The Mekong: Biophysical Environment of an International River Basin, Academic Press: New York, 464 p.

Attwood S.W., 2010. Studies on the parasitology, phylogeography and the evolution of host-parasite interactions for the snail intermediate hosts of medically important trematode genera in Southeast Asia. Adv. Parasitol. 73 : 405-440.

Attwood S.W. \& Upatham E.S., 1999. A new strain of Neotricula aperta found in Khammouanne Province, central Laos, and its compatibility with Schistosoma mekongi. J. Molluscan Stud. 65 : 371374.

Attwood S.W. \& Upatham E.S., 2012. Observations on Neotricula aperta (Gastropoda: Pomatiopsidae) population densities in Thailand and central Laos: implications for the spread of Mekong schistosomiasis. Parasit. Vectors $5: 126$.

Attwood S.W., Fatih F.A., Campbell I.C. \& Upatham E.S., 2008. The distribution of Mekong schistosomiasis, past and future: preliminary indications from an analysis of genetic variation in the intermediate host. Parasitol. Int. 57 : 256-270.

Brandt R.A., 1968. Descriptions of new nonmarine mollusks from Asia. Arch. Für Molluskenkd. 98 : 213-289.

Brandt R.A., 1970. New freshwater gastropods from the Mekong. Arch. Für Molluskenkd. 100 : 183-205.

Brandt R.A., 1974. The non-marine mollusca of Thailand. Arch. Für Molluskenkd. 105 : 1-423.

Brandt R.A. \& Temcharoen P., 1971. The molluscan fauna of the Mekong at the foci of schistosomiasis in South Laos and Cambodia. Arch. Für Molluskenkd. 101: 111-140.

Chanudet V., Guédant P., Rode W., Guérin F., Serça D., Deshmukh C. \& Descloux S. Evolution of the physico-chemical water quality in the Nam Theun 2 Reservoir for the first 5 years after impoundment. Hydroécol. Appl. 19 (same issue).

Combes C., Albaret J.-L., Arvy L., DuretteDesset M.-C., Gabrion C. \& Jourdane J., 1980. Atlas Mondiales des Cercaires. Mémoires Muséum Natl. Hist. Nat. A115 : 1-235.

Davis G.M., 1979. The origin and evolution of the gastropod family Pomatiopsidae, with emphasis on the Mekong river Triculinae. Acad. Nat. Sci. Phila. Monogr. $20: 1-120$.

De N.V., Murrell K.D., Cong L.D., Cam P.D., Chau L.V. \& Toan N.D., 2003. The foodborne trematode zoonoses of Vietnam. Southeast Asian J. Trop. Med. Public Health 34 Suppl. 1 : 12-34.

Descloux S., Guédant P., Phommachanh D. \& Luthi R. Main features of the Nam Theun 2 hydroelectric project (Lao PDR) and the associated environmental monitoring programme. Hydroécol. Appl. 19 (same issue). 
Ditrich O., Nasincova V., Scholz T. \& Giboda M., 1992. Larval stages of medically important flukes (Trematoda) from Vientiane Province, Laos. Part II. Cercariae. Ann. Parasitol. Hum. Comp. 67 : 75-81.

Kimura E., Uga S., Migwi D.K., Mutua W.R., Kiliku F.M. \& Muhoho N.D., 1994. Hourly change in cercarial densities of Schistosoma haematobium and S. bovis at different depths in the water and distances from the shore of a dam in Kwale District, Kenya. Trop. Med. Parasitol. Off. Organ Dtsch. Tropenmedizinische Ges. Dtsch. Ges. Für Tech. Zusammenarbeit GTZ 45 : 112-114.

Kloos H., Gardiner C.H., Selim A. \& Higashi G.I., 1982. Laboratory and field evaluation of a direct filtration technique for recovery of schistosome cercariae. Am. J. Trop. Med. Hyg. 31 : 122-127.

Kolárová L., 2007. Schistosomes causing cercarial dermatitis: a mini-review of current trends in systematics and of host specificity and pathogenicity. Folia Parasitol. (Praha) 54 : 81-87.

Kruatrachue M., Bhaibulaya M., Chesdapan C. \& Harinasuta C., 1968. Trichobilharzia maegraithi sp. nov., a cause of cercarial dermatitis in Thailand. Ann. Trop. Med. Parasitol. 62 : 67-73.

Kullavanijaya P. \& Wongwaisaya H., 1993. Outbreak of cercarial dermatitis in Thailand. Int. J. Dermatol. 32 : 113-115.

Liu L., Mondal M., Idris M., Lokman H., Rajapakse P.J. \& Satrija F., 2010. The phylogeography of Indoplanorbis exustus (Gastropoda: Planorbidae) in Asia. Parasit. Vectors 3 : 57.

Liu Z. \& Bai G., 1976. On bird schistosomes from Jilin Province: Jilinobilharzia crecci gen. nov., sp. nov. (Schistodomatidae: Bilharziellinae) with a discussion on the taxonomy of the subfamily Bilharziellinae. Acta Zool. Sin. 22 : 385-392.
Liu Z., Chen M., Jin G., Tan Y. \& Yang F., 1977. A survey of the aetiological agent of paddy field dermatitis in Ji'an Xian, Jilin Province, with preliminary observations of the life history of Trichobilharzia jianensis sp nov (Trematoda: Schistosomatidae). Acta Zool. Sin. 23 : 161-174.

Muhoho N.D., Katsumata T., Kimura E., Migwi D.K., Mutua W.R. \& Kiliku F.M., 1997. Cercarial density in the river of an endemic area of schistosomiasis haematobia in Kenya. Am. J. Trop. Med. Hyg. 57 : 162-167.

Mulvihill C.A. \& Burnett J.W., 1990. Swimmer's itch: a cercarial dermatitis. Cutis Cutan. Med. Pr. 46 : 211-213.

Narain K. \& Mahanta J., 2000. Dermatitis associated with paddy field environment in Assam, India: A review. In: Bhasin M.K. \& Bhasin V. (Eds.), Man-Environment Relationship, Human Ecology Special Issue. Kamla-Raj: Kolkatta 9 : 213-220.

Narain K., Rajguru S.K. \& Mahanta J., 1998. Incrimination of Schistosoma spindale as a causative agent of farmer's dermatitis in Assam with a note on liver pathology in mice. J. Commun. Dis. $30: 1-6$.

Nithiuthai S., Anantaphruti M.T., Waikagul J. \& Gajadhar A., 2004. Waterborne zoonotic helminthiases. Vet. Parasitol. 126 : 167193.

Palmieri J.R., Sullivan J.T. \& Ow-Yang C.K., 1977. A survey of snail hosts and larval trematodes collected in peninsular Malaysia and Singapore from 1972 to 1977. South East Asian J. Trop. Med. Public Heal. 8 : 275-277.

Prentice M.A., 1984. A field-evolved differential filtration method for recovery of schistosome cercariae. Ann. Trop. Med. Parasitol. 78 : 117-127.

Prentice M.A. \& Ouma J.H., 1984. Field comparison of mouse immersion and 
cercariometry for assessing the transmission potential of water containing cercariae of Schistosoma mansoni. Ann. Trop. Med. Parasitol. 78 : 169-172.

Tang C.-C. \& Tang C.-T., 1962. Studies on the life history of a dermatitis producing schistosome in Fukien and its infection experiments on the mammalian host. J. Fujian Norm. Univ. Soc. Sci. Ed. 2 : 1-44.
Therron A., 1986. Cercariometry and the epidemiology of schistosomiasis. Parasitol. Today Pers. Ed. 2 : 61-63.

Wächtler K., 2001. Reproductive Biology and Life History Strategy of Bithynia tentaculata (Linnaeus, 1758) and Bithynia leachii (Sheppard, 1823), Department of biology of the University of Hannover: Hannover. 